\author{
dr Anna Grzeszak \\ Uniwersytet Warszawski \\ Wydział Neofilologii, Katedra Hungarystyki \\ tel. (22) 5526077 \\ e-mail: anna.grzeszak@uw.edu.pl
}

\title{
JAK KORZYSTAJĄ ZE SŁOWNIKÓW STUDENCI MAŁYCH FILOLOGII?
}

\section{STRESZCZENIE}

Celem artykułu jest próba odpowiedzi na pytanie, w jakim stopniu dotychczasowe ustalenia dotyczące sposobu korzystania ze słowników przez osoby uczące się języków obcych (przede wszystkim języka angielskiego) są prawdziwe w odniesieniu do studentów Katedry Hungarystyki Uniwersytetu Warszawskiego, uczących się trzech mniej popularnych języków: fińskiego, węgierskiego oraz estońskiego. W artykule zaprezentowano wyniki badania ankietowego, które skupiało się wokół następujących zagadnień: 1) jak często studenci korzystają ze słowników, 2) jak często korzystają ze słowników poszczególnych typów, 3) jak oceniają słowniki, z których korzystają.

Słowa kluczowe: korzystanie ze słowników, język węgierski, język fiński, język estoński, słowniki dwujęzyczne, słowniki jednojęzyczne

\section{SUMMARY}

How do students of less commonly taught languages use dictionaries?

The paper attempts to answer the question to what extent the existing findings on the dictionary use (concerning mainly learners of English) are true for the students of the Department of Hungarian Language at the University of Warsaw, who learn three less commonly taught languages: Finnish, Hungarian and Estonian. The paper presents the results of a survey which 
focused on the following issues: 1) how often the students use dictionaries, 2) how frequently they use dictionaries of different types, 3 ) how they rate the dictionaries they use.

Key words: dictionary use, Hungarian language, Finnish language, Estonian language, bilingual dictionaries, monolingual dictionaries

\section{Wstęp}

Badania nad użyciem słowników języków obcych prowadzone są w ostatnich dziesięcioleciach z coraz większą intensywnością. Zdecydowana większość prac z tego obszaru koncentruje się wokół problemów związanych z korzystaniem ze słowników przez osoby uczące się powszechnie nauczanych języków, przede wszystkim języka angielskiego (por. m.in. prace Sue Atkins i Kristy Varantoli ${ }^{1}$, Jamesa Baxtera ${ }^{2}$, Henriego Béjointa ${ }^{3}$ oraz Roberta Lwa ${ }^{4}$ ). Celem przeprowadzonego badania była próba odpowiedzi na pytanie, w jakim stopniu dotychczasowe ustalenia są prawdziwe w odniesieniu do studentów Katedry Hungarystyki Uniwersytetu Warszawskiego, uczących się trzech mniej popularnych języków: fińskiego, węgierskiego oraz estońskiego. Oferta leksykograficzna dla osób studiujących te języki jest bardzo skromna. Liczba dostępnych słowników z fińskim, węgierskim i estońskim jest wielokrotnie mniejsza niż liczba słowników języka angielskiego, a istniejące opracowania leksykograficzne są mniej zróżnicowane. Wśród słowników dwujęzycznych dominują małe zbiory, w których liczba haseł nie przekracza dziesięciu tysięcy. Jeśli istnieją większe opracowania, to są to słowniki wydane przed kilkudziesięcioma laty, częściowo już przestarzałe. Dostępne są nowe, wielkie słowniki jednojęzyczne, są to jednak wydania adresowane przede wszystkim do rodzimych użytkowników fińskiego, węgierskiego czy estońskiego.

1 B. T. S. Atkins, K. Varantola, Monitoring dictionary use, „International Journal of Lexicography” 1997, 10 (1); B. T. S. Atkins, K. Varantola, Language learners using dictionaries: The final report on the EURALEX/AILA Research Project on Dictionary Use, [w:] Using dictionaries. Studies of dictionary use by language learners and translators, B. T. S Atkins (red.), Tübingen 1998.

2 J. Baxter, The dictionary and vocabulary behavior: A single word or a handful?, „TESOL Quaterly” 1980, 14 (3).

3 H. Béjoint, The foreign student's use of monolingual English dictionaries: A study of language needs and reference skills, „Applied Linguistics” 1981, 2 (3).

4 R. Lew, Which dictionary for whom? Receptive use of bilingual, monolingual and semi-bilingual dictionaries by Polish learners of English, Poznań 2004. 
Badanie miało charakter ankietowy i skupiało się wokół następujących zagadnień: 1) jak często studenci korzystają ze słowników, 2) z jakich słowników korzystają najczęściej, 3) jakie słowniki oceniają najwyżej. Zanim przedstawię i omówię wyniki ankiety, chciałabym krótko zreferować najważniejsze ustalenia dotyczące sposobu korzystania ze słowników przez osoby uczące się języków obcych, przede wszystkim języka angielskiego.

\section{Badania nad korzystaniem ze słowników}

Stan badań nad użyciem słowników został omówiony w dwóch pracach Roberta Lwa - książce z $2004^{5}$ oraz artykule z $2011^{6}$ roku. Ograniczę się zatem do bardzo szkicowego zreferowania tych opracowań, uzupełniając zestawienie o informacje o wynikach badań przeprowadzonych przez samego Lwa. Wspomnę jedynie o tych ustaleniach, które dotyczyły częstości korzystania ze słowników, preferencji użytkowników oraz sposobu oceniania przez nich różnych typów opracowań leksykograficznych.

Z dotychczasowych badań wynika, że ze słowników korzysta się rzadziej niż mogliby się tego spodziewać leksykografowie, metaleksykografowie oraz nauczyciele języków obcych. Próbowano sprawdzić, jak poziom znajomości języka wpływa na częstość sięgania po słownik. Wnioski, do jakich doszli badacze, są różne. Zdaniem Jerzego Tomaszczyka ${ }^{7}$ do słowników zaglądają częściej początkujący uczniowie, zdaniem innych badaczy ${ }^{8}$ to zaawansowani studenci są częstszymi użytkownikami.

Jeśli chodzi o preferencje dotyczące typów słowników, większość badaczy jest zgodna, że osoby uczące się języków obcych znacznie częściej sięgają się po słowniki dwujęzyczne niż po jednojęzyczne9. Wśród słowników dwujęzycznych prefe-

5 Ibidem.

6 R. Lew, Studies in dictionary use: recent developments, „International Journal of Lexicography” 2011, 24 (1).

7 J. Tomaszczyk, Dictionaries: Users and uses, „Glottodidactica” 1979, 12.

8 G. Hatherall, Studying dictionary use: Some findings and proposals, [w:] LEXeter '83 Proceedings: papers from International Conference on Lexicography at Exeter Hartmann, R. R. K. Hartmann (red.), Tübingen 1984; S. Knight, Dictionary use while reading: The effects on comprehension and vocabulary acquisition for students of different verbal abilities, „Modern Language Journal” 1994, 78 (3); M. Jakubowski, The use of dictionaries by high school learners: the place of the monolingual and bilingual dictionary in the learning process, Poznań 2001; U. Wingate, The effectiveness of different learner dictionaries. An investigation into the use of dictionaries for reading comprehension by intermediate learners of German, Tübingen 2002; R. Lew, op. cit.

9 Por. J. Tomaszczyk, op. cit.; M. Jakubowski, op. cit.; R. Lew, op. cit. 
rowane są słowniki, w których język obcy jest językiem źródłowym ${ }^{10}$. Oznacza to, że, na przykład, polscy studenci uczący się języka angielskiego wolą korzystać ze słowników angielsko-polskich niż polsko-angielskich. Słowniki jednojęzyczne są używane bardzo rzadko. Zainteresowanie opracowaniami tego typu wzrasta wraz ze znajomością języka: sięgają po nie przede wszystkim studenci bardzo zaawansowani, choć ciągle nie tak często jak po słowniki dwujęzyczne ${ }^{11}$.

Mimo wyraźnej preferencji dla słowników dwujęzycznych to jednojęzyczne zbiory cieszą się większym uznaniem ${ }^{12}$. Jeśli chodzi o opracowania dwujęzyczne, studenci wyżej oceniają słowniki, w których język rodzimy jest językiem docelowym od tych, w których jest językiem źrodłowym ${ }^{13}$. Przykładowo, polscy uczniowie bardziej cenią słowniki angielsko-polskie niż polsko-angielskie. Ursula Wingate $^{14}$ zauważyła również, że od słowników dwujęzycznych z językiem rodzimym większym uznaniem cieszą się słowniki dwujęzyczne z dwoma językami obcymi.

\section{Ankieta}

Ankieta została skonstruowana na wzór formularza opracowanego przez Lwa $^{15}$, nie jest jednak jego wierną adaptacją. Stworzono trzy wersje - dla osób uczących się języka fińskiego, węgierskiego oraz estońskiego. Każda wersja zawierała cztery pytania. W punkcie pierwszym wymieniono osiem, zdaniem autora ankiety, najpopularniejszych słowników jedno- i dwujęzycznych z danym językiem. Ankietowani zostali poproszeni o wskazanie, po które słowniki sięgają kilka razy w tygodniu, po które kilka razy w miesiącu, a po które rzadziej niż kilka razy w miesiącu lub wcale. Jeśli student korzysta ze słowników niewymienionych w zestawieniu, mógł je wskazać w punkcie drugim. W ostatnim, trzecim punkcie poproszono studentów o wymienienie dwóch najwyzej cenionych przez nich opracowań leksykograficznych. Wzór formularza w wersji przeznaczonej dla studentów uczących się języka fińskiego został przedstawiony w załączniku.

W założeniu w badaniu mieli wziąć udział wszyscy studenci Katedry Hungarystyki Uniwersytetu Warszawskiego. Studia w Katedrze trwają pięć i pół roku (prowadzone są czteroletnie studia licencjackie oraz półtoraroczne studia magi-

\footnotetext{
10 Por. R. Lew, op. cit.

11 Por. J. Tomaszczyk, op. cit.; B. T. S. Atkins, K. Varantola, Language learners using dictionaries; M. Jakubowski, op. cit.; H. Béjoint, op. cit.

12 Por. J. Tomaszczyk, op. cit.; J. Baxter, op. cit.; H. Béjoint, op. cit.; N. N. Kharma, Wanted: A brand new-type of learners' dictionary, „Multilingua” 1985, 4; R. Lew, op. cit.

13 Por. R. Lew, op. cit.

14 U. Wingate, op. cit.

15 R. Lew, op. cit., s. 205-206.
} 
sterskie). Studenci uczą się w ramach jednej z dwóch specjalizacji: fińskiej albo węgierskiej. Praktyczną naukę języka kierunkowego zaczynają na pierwszym roku studiów od poziomu zerowego, a kończą na ostatnim, szóstym roku. Zakłada się, że absolwent studiów magisterskich powinien opanować język kierunkowy na poziomie C2. Studenci trzeciego i czwartego roku uczą się dodatkowo drugiego języka ugrofińskiego. W ramach specjalizacji fińskiej można wybrać język węgierski lub estoński, a w ramach specjalizacji węgierskiej fiński lub estoński. Języki fiński i węgierski są zatem nauczane zarówno jako języki kierunkowe, jak i niekierunkowe, a język estoński wyłącznie jako język niekierunkowy. Po zakończonym dwuletnim kursie języka niekierunkowego student powinien wykazywać się znajomością tego języka na takim samym poziomie, jaki osiągnął $\mathrm{w}$ nauce języka kierunkowego pod koniec pierwszego roku studiów. W praktyce udaje się to jedynie nielicznym - większość studentów jest słabo zmotywowana do nauki drugiego języka ugrofińskiego, przez co osiąga gorsze efekty w nauce.

\section{Wyniki ankiety}

W badaniu wzięło udział 99 studentów. 28 z nich wypełniło po dwie ankiety - jedną dotyczącą korzystania ze słowników podczas nauki języka kierunkowego, a drugą poświęconą słownikom z językiem niekierunkowym. W efekcie uzyskano 127 ankiet. Badanie zostało przeprowadzone wiosną 2015 roku. W tym czasie w Katedrze Hungarystyki nie odbywały się studia na III i V roku specjalizacji fińskiej oraz na VI roku obu specjalizacji. Poniższa tabela przedstawia, ile osób $\mathrm{z}$ poszczególnych grup wzięło udział w badaniu. $W$ oznacza grupę studentów uczących się języka węgierskiego, $F$ - fińskiego, $E$ - estońskiego. Kolejne cyfry arabskie odnoszą się do roku studiów. Skrót $n k$ służy oznaczeniu grupy studentów uczących się danego języka jako niekierunkowego. Symbol F1 odsyła zatem do grupy studentów III roku specjalizacji fińskiej odpowiadających na pytania dotyczące sposobu korzystania ze słowników podczas nauki języka fińskiego. Symbol Fnk oznacza grupę studentów specjalizacji węgierskiej (są to studenci III oraz IV roku) uczęszczających na kurs języka fińskiego jako drugiego języka ugrofińskiego.

Tabela 1. Rozkład ankiet ze względu na język oraz stopień jego znajomości u ankietowanych

\begin{tabular}{|l|c|c|c|c|c|c|c|c|c|c|c|c|c|c|}
\hline Grupa & Wnk & W1 & W2 & W3 & W4 & W5 & W & Fnk & F1 & F2 & F4 & F & Enk & WFE \\
\hline $\begin{array}{l}\text { Liczba } \\
\text { ankiet }\end{array}$ & 7 & 16 & 18 & 11 & 4 & 6 & 62 & 13 & 21 & 10 & 13 & 57 & 8 & 127 \\
\hline Udział \% & 6 & 13 & 14 & 9 & 3 & 5 & 49 & 10 & 17 & 8 & 10 & 45 & 6 & 100 \\
\hline
\end{tabular}


Większość badanych studentów to osoby, które nie opanowały danego języka w stopniu zaawansowanym. 51\% wszystkich ankiet pochodziło od studentów uczących się trzech języków ugrofińskich na najniższym poziomie, to jest od studentów I roku oraz studentów uczęszczających na kurs niekierunkowy. Ankiety rozłożyły się nierównomiernie również pod względem badanego języka. O ile liczba uzsykanych formularzy dotyczących nauki języka fińskiego niewiele różni się od liczby ankiet wypełnionych przez studentów języka węgierskiego, o tyle liczba osób uczących się języka estońskiego jest znacząco niższa. Ten brak zrównoważenia wynika ze struktury kursów językowych prowadzonych w Katedrze oraz tego, że niewielu studentów kontynuuje naukę na wyższych latach.

\section{Jak często studenci korzystają ze słowników?}

Badanie wykazało, że większość studentów korzysta ze słownika co najmniej kilka razy w tygodniu. Jedynie osiem osób odpowiedziało, że nie sięga po żaden słownik częściej niż kilka razy w miesiącu. Żaden z ankietowanych nie używa słowników rzadziej.

Tabela 2. Czestość korzystania ze słowników na poszczególnych poziomach

\begin{tabular}{|l|c|c|c|c|c|c|c|}
\hline Grupa & Nk & $\mathbf{1}$ & $\mathbf{2}$ & $\mathbf{3}$ & $\mathbf{4}$ & $\mathbf{5}$ & Razem \\
\hline $\begin{array}{l}\text { Kilka razy } \\
\text { w tygodniu }\end{array}$ & 23 & 34 & 28 & 11 & 17 & 6 & 119 \\
\hline $\begin{array}{l}\text { Kilka razy } \\
\text { w miesiącu }\end{array}$ & 5 & 3 & 0 & 0 & 0 & 0 & 8 \\
\hline Rzadziej & 0 & 0 & 0 & 0 & 0 & 0 & 0 \\
\hline
\end{tabular}

Osoby korzystające ze słowników kilka razy w miesiącu to wyłącznie studenci I roku oraz studenci z grup niekierunkowych, a więc uczniowie początkujący. Wciąż jednak stanowią oni niewielki odsetek w swoich grupach: wśród studentów I roku to zaledwie $8 \%$, a wśród uczestników lektoratów niekierunkowych $18 \%$.

\section{Z jakich słowników studenci korzystają najczęściej?}

Osoby uczące się języka węgierskiego najczęściej zaglądają do następujących słowników: E-bratanki.hu (37 osób), Szótár.sztaki.hu w wersji polsko-węgiersko-polskiej (20 osób), Tłumacz Google w wersji angielsko-węgiersko-angielskiej (19 osób), Wielki słownik węgiersko-polski pod redakcją Jana Reychmana ${ }^{16}$ (11 osób) oraz Bab.la w wersji angielsko-węgiersko-angielskiej (10 osób). Pierwsze dwa słowniki zawierają ten sam materiał leksykalny i są opracowane w taki sam sposób

16 Wielki słownik węgiersko-polski, J. Reychman (red.), Warszawa 1968/1980. 
- na stronie Szótár.sztaki.hu prezentowana jest zawartość słownika E-bratanki. E-bratanki to darmowy słownik internetowy tworzony przez amatorów. Do tej pory zarejestrowano w nim około 20000 par wyrażeń. Tłumacz Google to popularne, choć niedoskonałe internetowe narzędzie do tłumaczenia, oparte na wielkiej bazie tekstów równoległych. Tłumacz może być również wykorzystywany jako słownik. Narzędzie jest wielojęzyczne, tłumaczy teksty lub wyrażenia wielu języków na wiele innych języków, w tym języka węgierskiego na polski i odwrotnie. Studenci jednak korzystają przede wszystkim z wersji angielsko-węgiersko-angielskiej. Wielki słownik wegiersko-polski to jedyny słownik drukowany cieszący się popularnością wśród hungarystów. Po raz pierwszy został wydany w 1968 roku; drugie, nieznacznie zmienione wydanie ukazało się w roku 1980. Słownik zawiera około 140000 haseł. Został opracowany przez zespół osób związanych z ośrodkami akademickimi w Polsce i na Węgrzech. Powstał jako druga część wydanego w 1958 roku Słownika polsko-wegierskiego pod redakcją Tibora Csorby ${ }^{17}$. Piąty najpopularniejszy słownik, Bab.la to słownik internetowy oparty na zewnętrznej bazie tłumaczeń tekstów w wielu językach. Mimo że istnieje wersja polsko-węgiersko-polska, studenci częściej korzystają ze słownika w wersji z językiem angielskim. Nie udało mi się ustalić wielkości tego zbioru. Słowniki jednojęzyczne okazały się niepopularne wśród hungarystów - zaledwie dziewięć osób przyznało, że korzysta często z internetowego Wikiszótár.hu, a nikt nie wskazał w drugim punkcie formularza żadnego jednojęzycznego słownika akademickiego.

Osoby uczące się języka fińskiego najczęściej sięgają do Kielitoimiston sanakirja (28 studentów). Jest to akademicki słownik jednojęzyczny dostępny zarówno w wersji drukowanej ${ }^{18}$, jak i nieustannie aktualizowanej wersji internetowej. Zawiera ponad 100000 haseł. Drugim najpopularniejszym słownikiem jest internetowe, wielojęzyczne Wiktionary.org (25 osób). Artykuły hasłowe w tym słowniku zawierają zarówno fińskojęzyczne definicje, jak i odpowiedniki w innych językach. Słownik tworzony jest na zasadzie otwartej treści - każdy użytkownik może sam opracowywać hasła. Wiktionary.org rejestruje około 7000 fińskich wyrażeń. Trzecim słownikiem najczęściej wskazywanym przez studentów jest Sanakirja. org w wersji angielsko-fińsko-angielskiej (18 osób). Jest to wielojęzyczny słownik internetowy oparty częściowo na materiale Wiktionary.org. Czwartym najpopularniejszym źródłem okazał się Tłumacz Google w wersji angielsko-fińsko-angielskiej (17 osób), a piątym polsko-fińsko-polski słownik Glosbe.com (14 osób). Glosbe to kolejny internetowy słownik wielojęzyczny oparty na bazie tłumaczeń i korzystający z innych narzędzi oraz zasobów, między innymi z Tłumacza Google. Drukowane słowniki z językiem polskim i fińskim okazały się znacznie mniej

17 Słownik polsko-węgierski, T. Csorba (red.), Budapest 1958/1985.

18 Kielitoimiston sanakirja, E. R. Grönros et al. (red.), Helsinki 2006. 
popularne - 4 studentów przynało, że często korzysta z małego Słownika polskofińskiego, fińsko-polskiego, wydawnictwa Level Trading ${ }^{19}$, a zaledwie pojedyncze osoby odpowiedziały, że najczęściej sięgają do większych wydawnictw: słowników Czesława Kudzinowskiego ${ }^{20}$ oraz Stanisława Wałęgi ${ }^{21}$.

Studenci uczęszczający na lektorat języka estońskiego korzystają przede wszystkim z Tłumacza Google w wersji angielsko-estońsko-angielskiej (4 osoby). Niektórzy zaglądają również do internetowych słowników z językiem angielskim udostępnionych na stronie Keeleveeb.ee: Nastik (2 osoby) oraz Aare (1 osoba). Oba słowniki opierają się na bazie leksykalnej estońsko-angielskiej stworzonej w Instytucie Języka Estońskiego i prezentują bardzo podobny materiał. Niektórzy studenci przyznali, że korzystają również z internetowych słowników polsko-estońsko-polskich: Eesti.pl oraz Glosbe.com (po 1 osobie). Okazało się, że nikt nie korzysta ani ze słowników jednojęzycznych, ani z dwujęzycznych słowników drukowanych, w których wyrażenia estońskie zestawiono z wyrażeniami języka polskiego.

Po zsumowaniu wyników otrzymanych we wszystkich grupach studenckich okazuje się, że największą popularnością cieszą się słowniki dwujęzyczne. Studenci korzystają najczęściej z opracowań z językiem angielskim, jednakże słowniki dwujęzyczne z językiem polskim używane są niewiele rzadziej. Opracowania jednojęzyczne również okazały się dość popularne, lecz wyłącznie wśród studentów uczących się języka fińskiego. Ankietowani, korzystając ze słowników dwujęzycznych, wybierają przede wszystkim takie, w których pary odpowiadających sobie wyrażeń dwu języków prezentowane są w obu kierunkach. Być może wynika to $\mathrm{z}$ tego, że studenci preferują słowniki internetowe, a te zwykle są dwukierunkowe. Wśród słowników jednokierunkowych popularniejsze okazały się wydania z językiem ugrofińskim jako źródłowym. Wykres nr 1 przedstawia, jakie typy słowników są najczęściej używane przez studentów. Skróty $A N G, P L, F R, W E$ oznaczają, odpowiednio, słowniki z językiem angielskim, polskim, francuskim i włoskim. Symbol $P L(c)$ odsyła do słowników z językiem polskim jako docelowym, $P L(z)$ do słowników z językiem polskim jako źródłowym, a $P L$ do słowników dwukierunkowych.

Jeżeli przyjrzymy się preferencjom studentów na różnych poziomach nauki języka, okaże się, że słowniki z językiem angielskim są najpopularniejsze wśród początkujących uczniów. Tabela nr 3 przedstawia, ile słowników poszczególnych typów zostało wskazanych jako najczęściej używane przez studentów uczących się na sześciu różnych poziomach.

19 Stownik polsko-fiński, fińsko-polski (wydawnictwo Level Trading), Czernica 2009/2011/2012.

20 C. Kudzinowski, Stownik fińsko-polski, Poznań 1988.

21 S. Wałęga, Słownik fińsko-polski, Warszawa 1978; S.Wałęga, Słownik polsko-fiński, Warszawa 1986. 
Wykres 1. Najczęściej używane słowniki według typów - wszystkie grupy

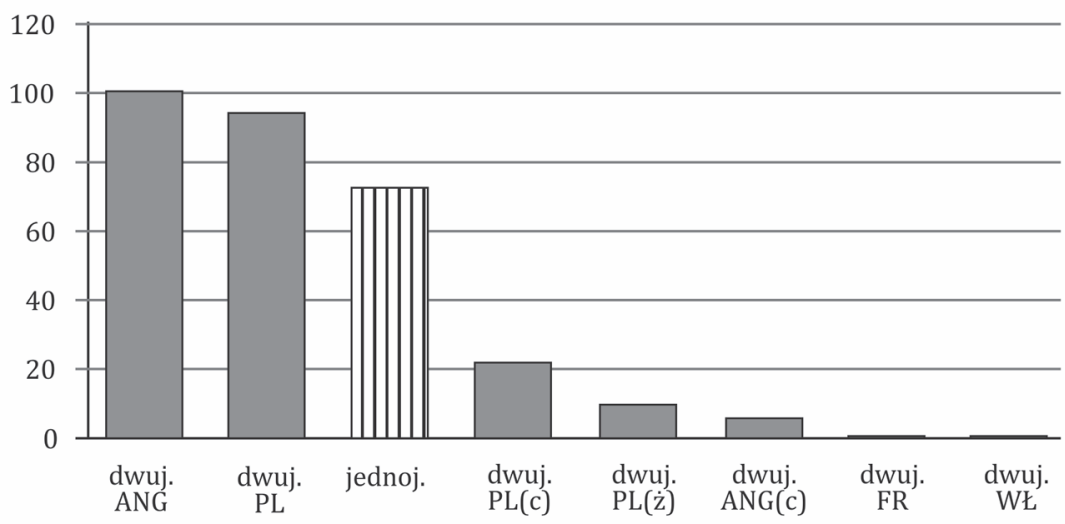

Tabela 3. Najczęściej używane typy słowników na poszczególnych poziomach

\begin{tabular}{|l|r|r|r|r|r|r|c|}
\hline & Nk & $\mathbf{1}$ & $\mathbf{2}$ & $\mathbf{3}$ & $\mathbf{4}$ & $\mathbf{5}$ & Razem \\
\hline Dwuj. ANG & 19 & 32 & 19 & 10 & 19 & 1 & 100 \\
\hline Dwuj. PL & 12 & 26 & 26 & 14 & 10 & 7 & 95 \\
\hline Jednoj. & 2 & 22 & 15 & 4 & 29 & 1 & 73 \\
\hline Dwuj. PL(c) & 0 & 3 & 4 & 6 & 5 & 4 & 22 \\
\hline Dwuj. PL(ź) & 0 & 0 & 6 & 1 & 3 & 0 & 10 \\
\hline Dwuj. ANG(c) & 0 & 0 & 1 & 5 & 0 & 0 & 6 \\
\hline Dwuj. FR & 1 & 0 & 0 & 0 & 0 & 0 & 1 \\
\hline Dwuj. WŁ & 0 & 0 & 0 & 1 & 0 & 0 & 1 \\
\hline
\end{tabular}

Wraz z poszerzaniem kompetencji językowych wzrasta użycie słowników z językiem polskim oraz opracowań jednojęzycznych. Trudno jednak mówić o wyraźnej tendecji, zwłaszcza jeśli chodzi o użycie słowników drugiego typu.

Wykres 2. Najczęściej używane słowniki według formy — wszystkie poziomy nauczania

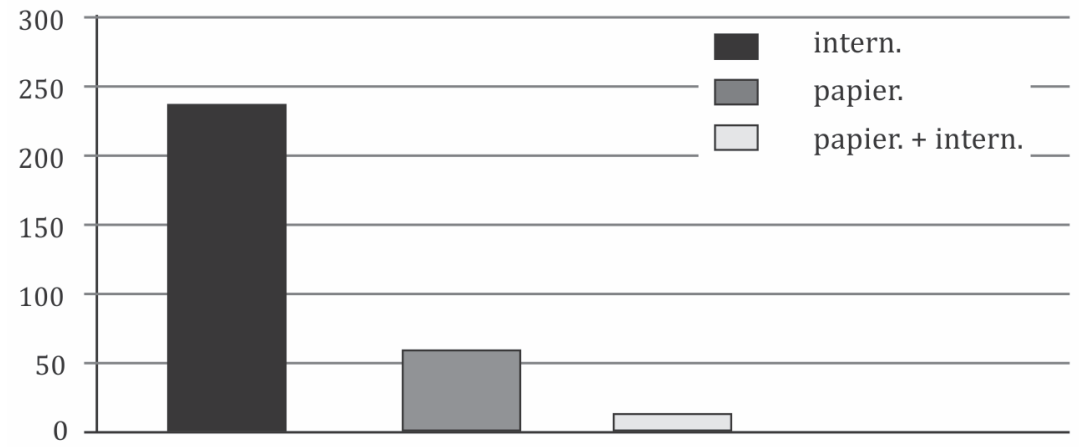


Wyraźna jest natomiast preferencja dla zbiorów udostępnianych w Internecie. Studenci zdecydowanie częściej korzystają ze słowników online niż ze słowników w formie papierowej. Tę preferencję ilustruje wykres nr 2.

Słowniki internetowe są najczęściej używanymi słownikami w każdej grupie studentów, niezależnie od poziomu znajomości języka. Nie jest zauważalny wzrost zainteresowania wydawnictwami drukowanymi wśród studentów wyższych lat.

\section{Jakie słowniki studenci oceniają najwyżej?}

Osoby uczące się języka węgierskiego najwyżej oceniły następujące słowniki: E-bratanki.hu (27 ankietowanych), Wielki słownik węgiersko-polski (18), Szótár. sztaki.hu w wersji z językiem polskim (11), Bab.la w wersji z językiem angielskim (8) oraz drukowany słownik węgiersko-angielski pod redakcją László Országha i Tamása Magaya z 2012 roku² $^{22}$ (6). Cztery z pięciu wymienionych słowników (oprócz ostatniego) to opracowania, po które studenci sięgają najczęściej. Warto zwrócić uwagę na wysoką pozycję Wielkiego słownika węgiersko-polskiego, który w rankingu najczęściej używanych zbiorów zajmuje dopiero czwartą pozycję. Wśród pięciu najwyżej ocenianych pomocy zabrakło popularnego wśród studentów Tłumacza Google.

Fenniści najbardziej cenią Kielitoimiston sanakirja (26 osób), Wiktionary. org (17), Sanakirja.org w wersji z językiem angielskim (14), Glosbe.com w wersji polsko-fińsko-polskiej (9) oraz drukowany Słownik fińsko-polski pod redakcją Kudzinowskiego (5). Ten ostatni to słownik rzadko używany przez studentów, a mimo to uznany za jeden $\mathrm{z}$ najlepszych. Fenniści, podobnie jak hungaryści, nie cenią Tłumacza Google. Wszystkie pozostałe najpopularniejsze słowniki zostały również najwyżej ocenione, w takiej samej kolejności.

Studenci uczący się języka estońskiego za najlepsze uznali dwa słowniki internetowe zestawiające wyrażenia estońskie z wyrażeniami angielskimi: Nastik (5 ankietowanych) oraz Aare (3). Pojedyncze osoby wysoko oceniły również Tłumacza Google (2), Eesti.pl (2), Glosbe.com w wersji z językiem angielskim (1) oraz estońskie Wiktionary.org (1). W tym rankingu zwraca uwagę przede wszystkim stosunkowo niska pozycja Tłumacza Google oraz obecność Wiktionary.org, z którego żaden ze studentów nie korzysta częściej niż kilka razy w miesiącu.

Poniższy wykres przedstawia, jakie słowniki są najwyżej oceniane przez wszystkich ankietowanych studentów. Słowniki zostały pogrupowane według typów.

22 Magyar-angol szótár, L. Országh, T. Magay (red.), Budapest 2012. 
Wykres 3. Najwyżej oceniane słowniki według typów - wszystkie poziomy nauczania

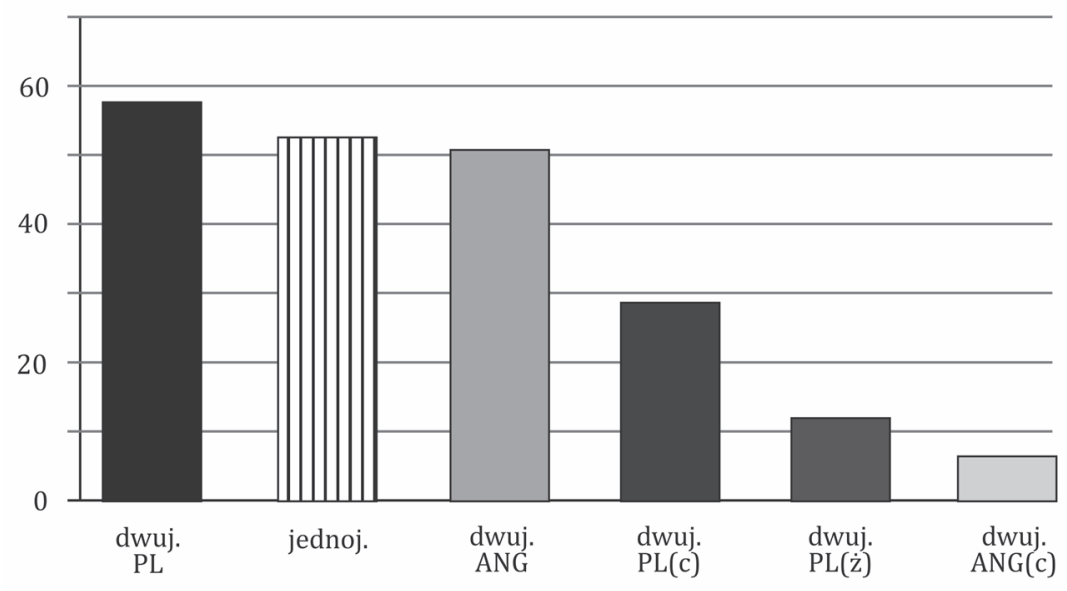

Słowniki dwujęzyczne z językiem angielskim są najczęściej używanym typem słowników, jednakże studenci oceniają je niżej niż słowniki dwujęzyczne z językiem polskim oraz opracowania jednojęzyczne. Różnice w ocenie wszystkich trzech typów nie są znaczące. Kolejność pozostałych typów jest taka sama jak w wypadku najczęściej używanych pomocy leksykograficznych. Słowniki, w których język ugrofiński jest językiem źródłowym, a polski lub angielski docelowym, okazały się wyżej oceniane niż słowniki z docelowym językiem ugrofińskim.

Kolejna tabela przedstawia, jakie słowniki uznali za najlepsze studenci na poszczególnych poziomach nauczania.

Tabela 4. Najwyżej oceniane typy słowników na poszczególnych poziomach

\begin{tabular}{|l|r|r|r|r|r|r|c|}
\hline & Nk & $\mathbf{1}$ & $\mathbf{2}$ & $\mathbf{3}$ & $\mathbf{4}$ & $\mathbf{5}$ & Razem \\
\hline Dwuj. PL & 11 & 23 & 14 & 5 & 1 & 4 & 58 \\
\hline Jednoj. & 8 & 15 & 11 & 0 & 19 & 0 & 53 \\
\hline Dwuj. ANG & 13 & 12 & 12 & 7 & 6 & 1 & 51 \\
\hline Dwuj. PL(c) & 3 & 4 & 7 & 4 & 6 & 5 & 29 \\
\hline Dwuj. PL(ź) & 2 & 0 & 7 & 1 & 2 & 0 & 12 \\
\hline Dwuj. ANG(c) & 0 & 0 & 1 & 5 & 0 & 0 & 6 \\
\hline
\end{tabular}

Słowniki dwujęzyczne z językiem polskim są najbardziej cenione przez studentów I, II oraz V roku, jednojęzyczne przez studentów IV roku, a dwujęzyczne z językiem angielskim przez osoby uczące się na III roku oraz przez uczestników lektoratów niekierunkowych. Trudno zatem mówić o wpływie poziomu znajomości języka na sposób oceny słowników.

Większość wysoko ocenionych zbiorów leksykograficznych to słowniki internetowe: 
Wykres 4. Najwyżej oceniane słowniki według formy — wszystkie poziomy nauczania

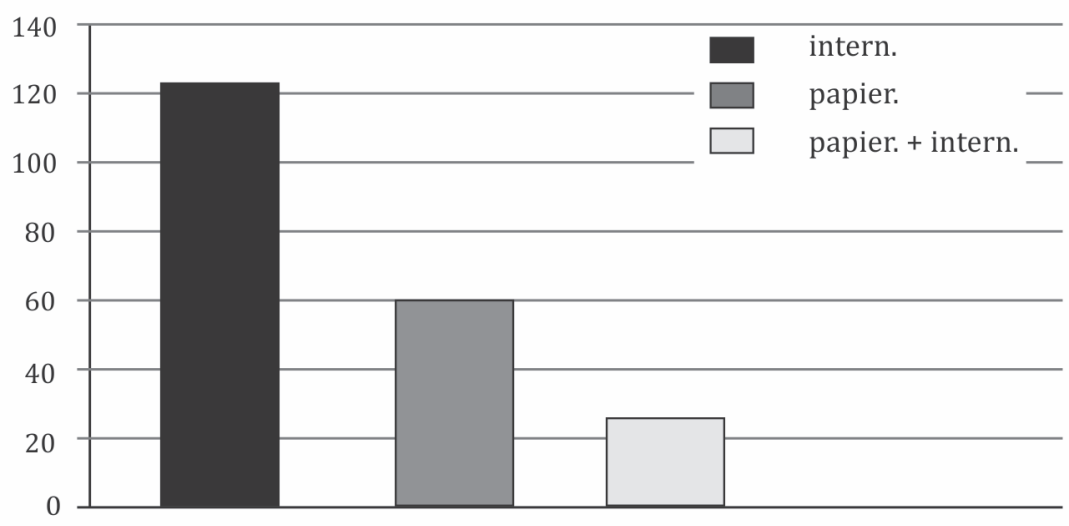

Różnica w ocenie słowników internetowych i papierowych nie jest tak znaczna jak wypadku częstości korzystania. Słowniki drukowane są rzadko używane przez studentów, lecz studenci je cenią.

\section{Wnioski}

Z przeprowadzonego badania wynika, że większość ankietowanych studentów korzysta ze słownika kilka razy w tygodniu. Rzadziej sięgają po słownik jedynie początkujący studenci. Potwierdziły się zatem ustalenia tych badaczy, którzy zaobserwowali, że zainteresowanie słownikami wzrasta wraz ze stopniem znajomości języka.

Studenci korzystają przede wszystkim ze słowników internetowych. Najchętniej sięgają po słowniki dwujęzyczne, przede wszystkim z językiem angielskim, w drugiej kolejności z językiem polskim. Częstość korzystania ze słowników z językiem angielskim maleje wraz z poziomem znajomości języka. Studenci chętniej korzystają ze słowników, w których języki węgierski, fiński i estoński są językami źródłowymi niż ze słowników, w których języki te są językami docelowymi.

Te wyniki są tylko częściowo zgodne $\mathrm{z}$ ustaleniami poczynionymi na podstawie badań przeprowadzonych wśród osób uczących się popularnych języków. Zgadza się preferencja dla słowników dwujęzycznych oraz opracowań ze źródłowym językiem obcym. Dla studentów Katedry Hungarystyki charakterystyczne jest to, że najczęściej sięgają po słowniki dwujęzyczne z językiem angielskim, a nie $\mathrm{z}$ językiem polskim. Wynika to najprawdopodobniej z braku odpowiednich słowników z językiem polskim lub ich gorszej dostępności. Wśród studentów 
Katedry nie zaobserwowano ani wyraźnie niższego zainteresowania słownikami jednojęzycznymi, ani wzrostu tego zainteresowania w grupie najbardziej zaawansowanych studentów. Osoby uczące się języka węgierskiego i estońskiego, zarówno początkujące, jak i zaawansowane, raczej nie korzystają w ogóle ze słowników jednojęzycznych, podczas gdy większość studentów filologii fińskiej sięga po opracowania tego typu dość często, niezależenie od poziomu znajomości języka. Taka sytuacja może wynikać z działań nauczycieli prowadzących zajęcia z praktycznej nauki języka fińskiego, nakłaniających studentów do korzystania z konkretnych opracowań leksykograficznych.

Mimo że studenci najczęściej sięgają po słowniki dwujęzyczne z językiem angielskim, nie oceniają ich tak wysoko jak dwujęzycznych z polskim oraz jednojęzycznych. Ta obserwacja pozostaje w sprzeczności $z$ wynikami dotychczasowych badań, wykazujących, że wyżej oceniane są słowniki jednojęzyczne oraz dwujęzyczne niezawierające wyrażeń w języku rodzimym. Poziom znajomości języka nie wpływa na opinie studentów Katedry o jakości słowników poszczególnych typów. Różnica w ocenie słowników internetowych i papierowych nie jest tak znaczna jak w wypadku częstości korzystania.

\section{Bibliografia}

Atkins B. T. S., Varantola K., Monitoring dictionary use, „International Journal of Lexicography” 1997, 10 (1).

Atkins B. T. S., Varantola K., Language learners using dictionaries: The final report on the EURALEX/ AILA Research Project on Dictionary Use, [w:] Using dictionaries. Studies of dictionary use by language learners and translators, B. T. S. Atkins (red.), Tübingen 1998, s. 21-81.

Baxter J., The dictionary and vocabulary behavior: A single word or a handful?, „TESOL Quaterly” 1980, 14 (3).

Béjoint H., The foreign student's use of monolingual English dictionaries: A study of language needs and reference skills, „Applied Linguistics” 1981, 2 (3).

Hatherall G., Studying dictionary use: Some findings and proposals, [w:] LEXeter '83 Proceedings: papers from International Conference on Lexicography at Exeter, R. R. K. Hartmann (red.), Tübingen 1984.

Jakubowski M., The use of dictionaries by high school learners: the place of the monolingual and bilingual dictionary in the learning process, Poznan 2001 (Praca magisterska).

Kharma N. N., Wanted: A brand new-type of learners' dictionary, „Multilingua” 1985, 4.

Knight S., Dictionary use while reading: The effects on comprehension and vocabulary acquisition for students of different verbal abilities, „Modern Language Journal” 1994, 78 (3).

Lew R., Which dictionary for whom? Receptive use of bilingual, monolingual and semi-bilingual dictionaries by Polish learners of English, Poznań 2004.

Lew R., Studies in dictionary use: recent developments, „International Journal of Lexicography” 2011, $24(1)$. 
Tomaszczyk J., Dictionaries: Users and uses, „Glottodidactica” 1979, 12.

Wingate U., The effectiveness of different learner dictionaries. An investigation into the use of dictionaries for reading comprehension by intermediate learnres of German, Tübingen 2002.

\section{Słowniki drukowane}

Kielitoimiston sanakirja, E. R. Grönros et al. (red.), Helsinki 2006.

Kudzinowski C., Słownik fińsko-polski, Poznań 1988.

Magyar-angol szótár, L. Országh, T. Magay (red.), Budapest 2012.

Słownik polsko-fiński, fińsko-polski (wydawnictwo Level Trading), Czernica 2009/2011/2012.

Stownik polsko-wegierski T. Csorba (red.), Budapest 1958/1985.

Wałęga S., Stownik fińsko-polski, Warszawa 1978.

Wałęga S., Słownik polsko-fiński, Warszawa 1986.

Wielki słownik węgiersko-polski, J. Reychman (red.), Warszawa 1968/1980.

\section{Załącznik:}

Formularz ankiety w wersji dla studentów uczących się języka fińskiego

\section{SŁOWNIKI W NAUCE JEZZYKA FIŃSKIEGO - ANKIETA}

Rok studiów:

Język kierunkowy:

1. Jak często korzystasz z wymienionych słowników?

$\begin{array}{ccc}\text { kilka razy } & \text { kilka razy } & \text { rzadziej } \\ \text { w tygodniu } & \text { w miesiącu } & \text { lub wcale }\end{array}$

Kielitoimiston sanakirja

Ilmainensanakirja.fi (suomi-puola)

Wiktionary.org

Stownik polsko-fiński, S. Wałęga

Stownik fińsko-polski, S. Wałęga

Słownik fińsko-polski, C. Kudzinowski

Sanakirja suomi-puola-suomi, A. Krawczykiewicz

Mały słownik polsko-fiński, J. Trypućko

Słownik minimum polsko-fiński, S. Ojaniemi,

H. Zgółkowa 
2. Czy korzystasz z innych słowników (również fińsko-angielskich, fińsko-niemieckich itd.) w nauce języka fińskiego? Jeśli tak, z których i jak często?

3. Które z dwóch używanych przez Ciebie słowników oceniasz najwyżej?

1.

2 . 